\title{
An Agenda for Improving Legal Claims for Medical Malpractice in Nigeria
}

\author{
Uwakwe Abugu $^{1} \&$ Dike C. Obalum ${ }^{2}$ \\ ${ }^{1}$ Department of Public and International Law, Faculty of Law, University of Abuja, Nigeria \\ ${ }^{2}$ Department of Surgery, State House Medical Centre, Aso Rock, Abuja, Nigeria \\ Correspondence: Uwakwe Abugu. E-mail: uwakoso@gmail.com
}

\author{
Received: March 9, $2018 \quad$ Accepted: March 19, $2018 \quad$ Online Published: April 19, 2018 \\ doi:10.5539/ass.v14n5p118 URL: https://doi.org/10.5539/ass.v14n5p118
}

\begin{abstract}
The law and ethics of medical practice enjoy a relatively universal appeal, and speak the same language in different jurisdictions. This is due mainly to the fact that the practice of modern orthodox medicine is traceable to the Greek philosopher, Hippocrates (father of modern medicine) who brought scientific rationalization into medical practice, thus exploding the hitherto garb of metaphysics and Esoterism that beclouded the practice. The various works of the World Medical Association in developing and disseminating ethical rules and standards of practice further strengthened the universal character of medical ethics. Accordingly, the right of patients and the duties of medical practitioners remain the same all over the world. But the extent to which these rights and duties are asserted, observed and enforced vary significantly among jurisdictions. Recent empirical investigation shows that in Nigeria only about $1.1 \%$ of all medical malpractice cases are enforced through legal action. This paper gives an analysis of the present state of medical practice in Nigeria in terms of the basic care exhibited by medical practitioners, the impression of patients about such care and other elementary requirements of doctor-patient relationship. It draws from a work which concludes that while the level of care is abysmally low leading to high level of malpractice, the level of legal claims is even lower. The paper proceeds to set out some legal and administrative remedial measures that could be taken to improve the almost non-existent claims against practitioners involved in medical malpractice in Nigeria.
\end{abstract}

Keywords: ADR, courthouse, incompetence, malpractice, medico- legal, misconduct, patient

\section{Introduction}

Malpractice appears to be an Achilles-heel that run across all the professions - legal, medical, engineering, etc. It is necessarily incidental to the frailty of man and the limitation of human wizardry in the delivery of professional services and it manifests in the delivery of such services in a manner below the accepted standard as a result of carelessness, recklessness, incompetence or negligence. It has been aptly defined as a legal term used in describing careless, wrong or illegal behaviour while in a professional job. ${ }^{1}$ Thus, we can talk of engineering failure leading to building collapse as a result of the engineer using substandard materials, a medical practitioner omitting appropriate follow-up care of his patient or a legal practitioner tampering with money received on behalf of his client.

In general, the manifestation or occurrence of a malpractice should be an isolated case in the professional life of any member of a profession. In other words, the training and skills acquired by a professional should ordinarily insulate him from any careless, reckless, negligent or incompetent behaviour in the practice of his profession. So, any deviation from the accepted norms and procedures for practice paints both the profession and the professional in a very bad light among members of the public. As a result, both the state and the professional body are equally concerned and regulate the code of conduct of the particular profession. ${ }^{2}$

However, the practice of medicine in Nigeria appears not to follow the general perception that malpractice among members of the profession should be an exception rather than the rule. Some of such malpractices prevalent in Nigeria include lack of due care such as failure to follow up a patient, lack of or improper

\footnotetext{
${ }^{1}$ Hornby, AS (ed.): Oxford Advanced Learner Dictionary of Current English (Oxford, Oxford University Press, $8^{\text {th }}$ Ed; 2010 ) p. 900

${ }^{2}$ For instance, while the Council of Legal Education regulates the legal profession in Nigeria, the Medical and Dental Council of Nigeria does so for the medical profession.
} 
consultation and reference, error in diagnosis, error in treatment or mistreatment, leaving foreign object within a patient, postoperative surgical hemorrhage, lack of or improper consent before treatment, transfusion of wrong or contaminated blood, error in prescribing medication, etc. ${ }^{3}$ Nigerian laws have made ample provisions to enable any patient who sustains medical malpractice to assert his claims, especially in court. Also, the law empowers the state to institute criminal proceedings to punish such malpractice where they indicate criminal elements. ${ }^{4}$ But in practice, these laws appear to be alive more in the statute books than in enforcement. Of course, the law can only act as an agent of social engineering when it is enforced, otherwise it would not be worth more than the parchment on which it is written.

\section{Analysis of Degree of Medical Malpractice and Legal Claims}

An empirical work by a researcher was devoted to finding out the impression of Nigerians about the care and treatment they receive from their doctors, the degree of medical malpractice claims by patients in Nigeria and the reasons for identified very low level of claims against doctors by patients ${ }^{5}$. It was discovered that $61.69 \%$ of Nigerian patients feel that Nigerian doctors are arrogant and careless about their patients' conditions and plights. ${ }^{6}$ Also 33.3\% of Nigerian patients indicated that their doctors' treatment had caused them extra injury beyond the ones that took them to the hospital. ${ }^{7}$ The doctor's malpractices which may lead to such extra or aggravated injury or pain include wrong drug prescription, impatience of doctors in taking and understanding the patients' medical history before prescription, etc. This is evident in some doctors who conclude their prescription even before the patients settle down to tell their stories. Other areas of malpractice where patients gave damning response of high prevalence in Nigeria include late or none detection of ailments or diseases, mistaken identity of patients, lack of, or improper consent to treatment, poor administration of consent forms, etc. ${ }^{8}$

In spite of the non-contestable high prevalence of malpractice as indicated by the responses, the level of claims remains abysmally low. To start with only, $40 \%$ of the respondents in the survey indicated that they were aware of their right to make claims against their doctors for negligence or carelessness. ${ }^{9}$ And only $1.1 \%$ of the whole respondents ever made a claim against their doctors in courts. ${ }^{10}$ The reasons offered by those interviewed for such low level of claims against doctors include poverty, illiteracy/ignorance, undue delay by courts, cultural inhibitions, religious beliefs, fear of the court and the enmity created between friends after court cases. ${ }^{11}$

The above statistics are surely the opposite of what obtains in the more advanced jurisdictions like the UK, USA, Canada and Australia. In these climes, the high level of medical malpractice claims and the amount of compensation awarded by the courts have led doctors to engage in the practice of defensive medicine or to some doctors closing practice. ${ }^{12}$ This yawning gap clearly shows that our medico- legal justice system requires a reform in the judicial and remedial system and a reform in the psyche of the populace. In the remaining part of this paper, some measures that could help to shore up the level of claims against medical practitioners with a view to improving our healthcare delivery system will be proposed.

\section{Improving Public and Medical Right Education by Agencies, NGOs and Faith Based Organisation}

It has already been shown that great numbers of Nigerian patients are not aware that they have the legal right to claim compensation for injury or damage caused to them by their doctors' malpractice. The first means of improving the awareness of patients of their rights in this regard is by adopting vigorous medical right education for members of the public. This may be undertaken by both government agencies and private organizations like non-governmental organizations (NGOs) and Faith Based Organisations. On the side of the government, the federal and state ministries of education should adopt aggressive measures that could instill the elementary

\footnotetext{
${ }^{3}$ Felicia Osagiede Ojo vs Dr. Gbararo \& UBTH Management Board, Unreported Suit No. B/24/91, Richardson v. Holmes 525 SW 2d293, Tex 1975, Keow v. Government of Malaysia (!967) 1 WLR 813.

${ }^{4}$ Sections 319 and 325 of the Criminal Code and Sections 221 and 224 of the Penal Code respectively make provision for the punishment of murder and manslaughter which may result from medical malpractice.

5 Abugu, U (2015): A Critical Appraisal of the Legal Regime for Medical Malpractice Claims in Nigeria (Ph.D. Thesis, Faculty of Law, University of Abuja. Cap 6 pp.414-441.

${ }^{6}$ Ibid at p. 424

7 Ibid at p.427.

${ }^{8}$ Ibid pp. 428-430

9 Ibid at p.434;

10 Ibid at p.435

11 Ibid at p.436-440

12 Dieter, G. International Medical Malpractice Law: A Comparative Study of Civil Liability Arising from Medical Care (Dordrecht, Tubingen Martinus Publishers, 1988) pp. 484-489 see also Northern Trust Cpy v. Grunty of Cook, 481 NE2 957 (III App 1985).
} 
knowledge of a citizen's right to receive adequate medical care from hospitals and doctors and the right to make claims where appropriate as part of their Health Education curriculum in primary and secondary schools throughout Nigeria. Also the Federal Ministry of Health and the National Orientation Agency should engage in direct education and medical rights advocacy in markets, schools and various places of worship.

It is important to note that the National Human Right Commission has taken a bold and commendable step in this regard, by establishing a unit known as the Human Right Education Unit. This Unit is in charge of human right enlightenment campaign and sensitization. It is primarily responsible for coordinating human rights activities in schools and other institutions as well as developing human rights curriculum for security training institutions. ${ }^{13}$ Other activities of the Unit include outreach programme, Human Right Clubs, In-house Human Right Education for staff and target group training. ${ }^{14}$ Whilst this is commendable, the Commission in addition to its current effort should emphasize health and medical right education as part and parcel of its human right education programme. This is especially as the Commission itself agrees that human right include right to good and adequate health. ${ }^{15}$

On the other hand, medical and health based NGOs should expedite action in educating the populace on their basic health and medical rights as citizens or as patients. One of such NGOs engaged in health and medical right education is the Foundation for Medical Rights of Nigerians. ${ }^{16}$ According to the Organization in its Brochure, "the need to create medical rights awareness in our society is long overdue" ${ }^{17}$. As such, the Organization adopts open air campaign, use of fliers, seminars conferences and workshops, collaboration with the media, town hall meetings, etc as road-map towards improving medical right education:. ${ }^{18}$

At present only few NGOs are into the promotion of health and medical rights. Legal, medical and other health care practitioners should establish more NGOs in this area.

The paucity of Medical Right based NGOs may be plugged by the intervention of Faith Based Organisations which weild veritable influence on their members. Faith Based Organisations should utilize their supervening influence on their members to disseminate information on the existence, types, the process and enforcement of medical and health rights of Nigerians. The organizations which are found among Christian, Islamic and other religious bodies have the added advantage of having the widest reach and geographical spread in the country. All such organization should work out a synergy for the purpose of articulating the content and modus operandi for achieving an enlightened and conscious populace on medical and health rights and their enforcement.

\section{Reform of Judicial and Remedial Approach}

\subsection{Why Conventional Court Is Not Suitable for Medical Malpractice Claims}

The old Latin maxim which forms the epicenter of the jurisprudence of justice delivery through the court is $u b i$ jus ibi remedium i.e. wherever there is a right, there must be a remedy. The application of this maxim ensures that no person or litigant is denied a remedy cognizable in law on the fanciful ground of lack of compliance with a particular form or procedure for enforcement. In other words, a person's right should be vindicated by the court irrespective of technical failure to comply with fanciful procedural rules.

This primordial rule now finds expression in the growing jurisprudence of what the court refer to as substantial justice. The doctrine of substantial justice expresses the desire of the court to ensure that justice is not slaughtered on the altar of technicality. Thus, in the case of Salbie \& Anor. v. INEC \& Ors, ${ }^{19}$ the Court of Appeal held that "the hay days of technicality are now over because the weight of judicial authorities has today shifted from reliance on technicalities to doing substantial justice even handedly to the parties in the case". ${ }^{20}$

However, for there to be justice or even substantial justice, the procedure, the result and the benefit of the justice system must be rendered in a timeous and expeditious manner. Otherwise, the promise of the justice system to render to every man what is due to him is utterly eroded and corroded by undue effluxion of time. In other words,

\footnotetext{
${ }^{13}$ National Human Right Commission, Annual Report 2011, p.11

${ }^{14}$ Ibid.

${ }_{15}$ National Action Plan for the Promotion and Protection of Human Rights in Nigeria, 2009-2013, p.61.

16 This NGO was established by Lawyers who were the first set of Law students taught Medical Law at the Faculty of Law, University of Abuja by this researcher in 2009 .

${ }^{17}$ Information Brochure, Foundation for Medical Rights of Nigerians.

${ }^{18}$ Ibid.

19 (2008-C.A) LPELR-CA/PH/EPT/3/2007

${ }^{20}$ Per Eso, JCA at P. 32 Para. A-D
} 
the aspiration to give remedy wherever there is a right or to ensure substantial justice may be rendered nugatory by undue delay in the justice delivery system. Thus, it has become a common adage that justice delayed is justice denied.

The effect of delay in the process of obtaining justice is not only against the present litigant in court but it is also a veritable disincentive to approaching the courts by would-be litigants for redress. In other words, an average litigant would measure the remedy he would obtain from the court against the length of time it would take the court to give such remedy. Accordingly, time taken to obtain justice is part and parcel of the cost of such justice.

The negative impact of delay in the justice system pervades all civil claims in courts including medical malpractice claims. It may be deduced that many medical malpractice claims may not have seen the light of the day simply because the affected patients have counted the cost of asserting the claims in terms of delay in the court process.

The following would give an insight into the cost of delay in the justice delivery system:

a. The case of Rossek and Ors. v. ACB Ltd \& Ors, ${ }^{21}$ was filed in 1975 and an order of retrial was given after 18 years of litigation.

b. A.J Lawal \& Anor v. Santus ${ }^{22}$ was pending at the High Court for 26years

c. S.A Abudu v. Alhaja T. Ogunbambi ${ }^{23}$ and Sipeolu \& Anor v. Allco Engineering Group Nig ${ }^{24}$ took 29 years and 25years respectively to conclude at the High Courts. ${ }^{25}$

The travail of the families of the victims of the Pfizer Troven Drug Trial is also a testimony of the effect of delay in medical malpractice related claims. During an epidemic of meningitis in Kano in 1996, Pfizer sent a team to test the efficacy of its new antibiotic "Trovafloxacin" (Trovan). The team conducted trial on about 200 children aged between 3 and 18 months, many of whom died after being administered with the antibiotic. Pfizer was consequently accused of conducting unethical and illegal tests on the victims with an unregistered drug. In 2001, 30 Nigerian families sued Pfizer in a Federal Court in New York. The suit alleged that Pfizer chose to select children to participate in a medical experiment of a new untested and unproven drug without first obtaining their consent. Pfizer challenged the jurisdiction of the New York Federal Court to hear the suit.

In August 2005, the judge, William H. Pauley, ruled that Nigeria rather than U.S was the proper place to try the case. But on January 30, 2009, a U.S Appeal Court in New York overturned the lower court's ruling on jurisdiction.

Meanwhile, 11years after the drug trial, the Kano State government in 2007, instituted a legal action at the Kano State High Court against Pfizer International and its Nigerian subsidiary along with some other notable leaders in the organization, ${ }^{26}$ accusing them of criminal conspiracy and deliberately causing grievous harm. It claimed N2 billion in damages.

The Federal Government equally instituted a separate suit against Pfizer at the Federal High Court, Abuja demanding \$7billion as damages and restitution. The Federal Government accused the company of violating Nigerian Laws, the International Declaration of Helsinki and the UN Convention on the Rights of the Child.

Both suits maintained that:

(a) Pfizer's researchers selected 200 children and infants from an epidemic camp in Kano and gave half of the group the untested antibiotic without obtaining the consent of the children's families;

(b) The researchers knew Trovan to be an experimental drug with life threatening side effects that was unfit for human use;

(c) Parents were banned from the ward where the drug trials took place;

(d) Families of the victims were led to believe and, in fact, understood that the defendants were providing them with volunteer relief, clearly focused humanitarian medical intervention and nothing more, and

${ }^{21}$ (1993) 8 NWLR (pt 312) 382

${ }^{22}$ Suit No LD/469/71 took 26 years

${ }^{23}$ Suit No. LD/89/74

${ }^{24}$ Suit No LD/4/78

${ }^{25}$ Sourced from the Speech made by Prof. M.M Akanbi, former Dean, Faculty of Law, University of Ilorin delivered at the formal inauguration of the committee on the proposed Kmara State Multi Door Court house at the High Court of Kmara State on $29^{\text {th }}$ July, 2008

${ }^{26}$ The story is taken from National Human Right Commission: The State of Human Rights in Nigeria, 2009-2010 (Abuja, NHRC, 2013) pp. $81-83$ 
(e) Parents were not informed that alternative treatments were available.

All the cases were consolidated in a negotiation where Pfizer agreed to pay $\$ 75$ million to the Federal Government, the Kano State Government and the affected families of the victims. ${ }^{27}$

The payment of the compensation has been mared in controversies due to the DNA Test precondition to payment. In May 2010, DNA experts arrived Kano State from the U.S to carry out DNA test on families of affected victims.

In our present contexts the Pfizer Trovan Test reveals the need for shorter procedure for vindicating civil claims generally and medical malpractice claims, in particular, in courts. This is because as shown in the Trovan case even, in U.S with its seeming seamless judicial system, it took 8 clear years (2001-2009) between the High Court and Appeal Court to decide on the issue of jurisdiction alone before the matter was to be heard on merit. Thanks to the wisdom of negotiation that led to the $\$ 75$ million settlement.

Closely related to undue delay in the justice delivery system is the clear battlefield usually drawn between the two litigating parties in adversarial system which operates in Nigeria. It has been demonstrated that $6.8 \%$ of Nigerians do not make medical malpractice claims against their doctors because court cases engender enmity between individual litigants and their families. ${ }^{28}$ This confirms the Yoruba proverb that "a ki ti kootu de ka sore" i.e. "you do not return from the court and remain friends". 29

Lord Woolf captured the adversity engendered by the adversarial system of justice when he said that "without effective judicial control, the adversarial process is likely to encourage adversarial culture and to degenerate into an environment in which the litigation process is too often seen as a battle field where no rules apply". 30

Apart from the cost of litigation, delay and loss of good relationship, the monetary expenses involved makes it out of reach for an average patient to vindicate any perceived infringement of his medical right. Oputa JSC (as he then was) summarized the inappropriateness of court in rendering justice in its present form when he said ${ }^{31}$ :

The administration of justice in our courts suffers from two major constraints, namely, delay and expense. If it takes 7-10 years to decide a case, a prospective litigant, may decide not to go to court at all. But the one thing that frightens litigants away from the court is the inordinate expense which has to be incurred with the result that a very large proportion of our country men are, as it were, priced out of the legal system. ${ }^{32}$

The following reforms in the judicial process would enhance access to justice to litigants in terms of time, expense and peace building and especially in vindicating uncountable rights to medical malpractice claims that have remained compromised in the past.

\subsection{Other Practical Approaches to Medical Malpractice Claims}

\subsubsection{Establishing Multi-Door Courthouse in all High Courts in Nigeria}

The growing idea of Multi-Door Courthouse was sparked off as far back as 1976 during a presentation at the Pound Conference on public dissatisfaction with the justice system by Professor Frank Sander of Harvard Law School. He offered an innovative approach that could ease the growing demand on courts throughout the country. Calling the concept, the Multi-Door Courthouse, Professor Sander envisioned one large courthouse with multiple dispute resolution doors or programmes. Cases could be diagnosed and referred through the appropriate door for resolution. The programmes could be located inside or outside of the courthouse and could include but not limited to litigation, conciliation, mediation, arbitration and social and governmental services. ${ }^{33}$

Sander's concept was very attractive to law reformers who were seeking alternatives for delay and congestion in the proceedings of the regular courts. Thus, the idea was accepted and started off experimentally in Tulsa,

\footnotetext{
${ }^{27}$ Ibid.

${ }^{28}$ Abugu, op. cit. p.440

${ }^{29}$ Ake, K.T: “Lagos multi-Door Courthouse”, LL.M Seminar Paper, Faculty of Law University of Abuja, 2010, p.2

${ }^{30}$ Ibid.

${ }^{31}$ Ibid, p. 1

32 Cited from Goodluck O.O: “Abuja Multi-Door courthouse: What Role in the Judicial Delivery System ?” presented at a seminar on Abuja

Multi-Door courthouse held at the High Court, Maitama, Abuja on 22/10/2009, p.1.

${ }^{33}$ Superior court of the District of Columbia, 1997 program summary, p. 1, cited in Ake, OP. Cite P.2.
} 
Oklahoma, Houston and Texas in 1985 and later in the Superior Court of the District of Columbia. ${ }^{34}$

The concept has gained tremendous ground in dispute resolution mechanisms in many advanced countries. In Nigeria the Lagos Multi-Door Courthouse (LMDC) which was officially declared open on $11^{\text {th }}$ June, 2002 by the then Chief Judge, Hon. Justice I.A Sotuminu was the first of its kind. In fact, the LMDC was the first Multi-Door Courthouse in Africa. ${ }^{35}$ Subsequently, the concept was replicated by the High Court of FCT (Federal Capital Territory), Abuja as the Abuja Multi-Door Courthouse (AMDC). It was commissioned on $13^{\text {th }}$ October, 2003. Also the Kano Multi-Door Courthouse (KMDC) was established in 2006. At present, there is an ongoing discussion with at least thirteen states judiciaries in Nigeria that have indicated interest in setting up the system in their jurisdictions. ${ }^{36}$

The overriding objective of the LMDC as contained in its Practice Direction is to "enlarge resources for justice by providing enhanced, timely, cost-effective and user friendly access to justice for would-be and existing plaintiff and defendants" ${ }^{37}$ Thus, while access to justice in regular courts is achieved through the "mono-door" of litigation, the Multi-Door Courthouse offer access to justice through Multi-Doors or options including but not limited to Mediation, Early Neutral Evaluation, Conciliation, Arbitration and Hybrid processes, eg Med-Arb (Mediation and Arbitration, Arb-Med (Arbitration and Mediation) and Med-Ene (Medication and Early Neutral Evaluation.

The beauty of resolution of civil disputes, especially medical malpractice claims through the courthouses is that apart from the process being almost fully funded by the State, ${ }^{38}$ any settlement reached may be enforced as the judgment of the appropriate High Court. For instance, in Lagos settlement agreements which are duly signed by the parties shall be enforced as contract between the parties and when such agreements are further endorsed by an ADR Judge they shall be enforceable as consent judgment of the High Court of Lagos State. ${ }^{39}$ Also, the High Court of Lagos State (Civil Procedure) Rules, 2004, states that an award made by an arbitrator or a decision reached at the Multi-Door Courthouse may, by the leave of a judge, be enforced in the same manner as a judgment or order of a court. ${ }^{40}$

One of the greatest achievements of the LMDC is the introduction of settlement week which is intended to encourage early settlement of cases pending in court and to provide satisfying solution, timely and cost-effective justice to litigants. During the 2009 Settlement Week by the LMDC, out of 100 matters scheduled for settlement, 14 were resolved before the week began, 35 were settled during the week while 32 were referred back to the courts; 14 matters were adjourned for further mediation session while 2 were partially settled. ${ }^{41}$

The case being made here is that with minimal advocacy and public enlightenment medical malpractice claims would astronomically rise if the Multi-Door Courthouse operating presently in Lagos, Abuja and Kano is replicated in all the State High Courts in Nigeria. The campaign for their spread throughout the states in Nigeria could be carried out by access to justice non-government organizations. (NGOs) and civil society organization (CSOs) like the Negotiation and Conflict Management Group (NCMG) which helped in midwifing the LMDC in collaboration with the U.S Embassy in Nigeria. ${ }^{42}$

\subsubsection{Designation of Special Courts for Medical Malpractice Claims}

Health is wealth and still remains the most prized possession of humankind. Thus, it is said that the health of a nation is the wealth of that nation. As such, all efforts must be geared towards upturning the general low level of medical malpractice claims in Nigeria. On such steps would be to designate special courts in both the inferior and superior courts in the states and the FCT for the purpose of trying medical malpractice cases. This policy would be more imperative in states that are yet to set up the Multi-Door Courthouses within their High Courts.

\footnotetext{
${ }^{34}$ Raymond L and Clere, A.I: "Multi Door Courthouse idea". Building courthouse of the future (Today 1985-1986) cited in Ugochukwu, A.O AbujaMulti-Door Courthouse, LL.M Seminar paper, Faculty of Law University of Abuja, 2010 p. 5

${ }^{35}$ Ake, OP. Cite p. 2

${ }^{36}$ Ibid, p. 3

${ }^{37}$ Ibid, p.6

${ }^{38}$ Filing fee and Administration fee could be as low as $2 \%$ and $1 \%$ of the amount claimed respectively. See AMDC scale of charges applicable to arbitration.

39 Section 19 of the LMDC Law, 2007

${ }^{40}$ Order 39, Rule 4(3)

${ }^{41}$ Adedimeji, A: "Lagos Multi-Door Court Wins ADR International Award" Cited at

https://www.independentngonline.com/dailyindependent/article.aspx as at 23.2:11

${ }^{42}$ The "Multi-Door" Concept in Nigeria: The Journey so far cited at https://www.ainablankson.com as at 12:10:10, se also Ake, Op. Cit, P.2
} 
Such courts should give top priority to medical malpractice claims in their Cause Lists and charge discriminating low fees in favour of indigent patients/claimants. Apart from reducing delay and expense of prosecuting claims, the court would serve as a veritable publicity of the availability of the right to make medical claims and the availability of ready forum for such claims.

Similarly, as a further avenue to publicize the availability of the right to make medical claims and reduce delay and expense of claims, each state judiciary could establish mobile courts designated at strategic locations within hospital premises, especial federal and state government hospital. The presence of such mobile courts within a shouting distance of the doctors and the patients would be a constant and relentless reminder for both that the long arm of law is readily available to punish or to compensate respectively.

\section{Reform of Medico-Legal Education and Law Reporting}

The role of the law in smoothening the rough edges of human relationship has been settled from time immemorial. The law sets the rules that govern the interaction between man and his neighbour, on the one hand and between a citizen and the state to which he belongs, on the other. In this regard, the lawyer, who has received special training in the principles and practice of law, its role in the society and the procedure for its enforcement is a veritable instrument of social engineering. As such he acts as the bee which carries the nectar and pollen of legal rights and duties of individuals and groups in the society to pollinate the unlearned minds of the members of the society.

\subsection{Medico-Legal Education}

It is against the above background that the view is taken here that any meaningful agenda for improving the level of medical malpractice claims in Nigeria must include a programme for giving sufficient instruction and training to legal practitioners' right from their university days as law students. It is observed that the only formal contact most legal practitioners has with medical law and ethics is with the study of the tort of negligence, and in particular, medical negligence. The tendency is for such legal practitioners to rationalize all issues involving medical malpractice from the point of view of medical negligence. But the law of medical negligence itself is grossly inadequate for the purpose of asserting, vindicating and enforcing all the medical rights of the patients who may consult such legal practitioner for legal advice and representation.

Thus, while the law of medical negligence may cover such themes as consent to medical treatment, disclosure of relevant information, referral, follow-up and observation, leaving foreign object within the patient, etc, it may not sufficiently address such themes as mistreatment, the content and limit of therapeutic privilege, medical and health rights as human rights and the right of autonomy and self-determination of a patient. In this regard the National Human Right Commission has remarked or cathedra:

It is imperative to note that the right to health is vital to all aspects of a person's life and wellbeing, and is crucial to the realization of many other fundamental human rights and freedoms, and that every woman, man, youth and child has the human right to the highest attainable standard of physical and mental health without discrimination of any kind ${ }^{43}$.

There is the need for the Nigerian lawyer to be equipped with the comprehensive knowledge of all the issues relating to the legal rights and obligation of the doctors and the patients in the cause of their doctor/patient relationship. This can be achieved by the introduction of the teaching of Medical Law and Ethics in all the faculties of law in Nigeria.

At present only very few faculties of law offer this course at the undergraduate level. The impact of the introduction of this course in the law faculties in Nigeria may be gleaned from the impact which law graduate from the Faculty of Law, University of Abuja (where the course is on offer), are making in the enforcement of medical rights of patients. A group of lawyers who were the pioneer students of the course in the faculty and who were called to the Nigerian Bar in 2011 came together to found an NGO known as Foundation for Medical Rights of Nigerians. The following are the aims and objectives of the Foundation:

1. To promote medical rights of Nigerians;

2. To promote patients/medical personnel relationship;

3. To promote good medical environment;

${ }^{43}$ The State of Human Rights in Nigeria, 2009-2010: A Report of the State of Human Rights Situation monitored in Nigeria by the National Human Rights Commission in collaboration with the Network of Human Rights Monitors, 2013, p.77 
4. To give legal support to patients as well as medical personnel;

5. To educate patients on their rights and obligations;

6. To educate medical personnel on their rights and obligations

7. To award scholarship to deserving students; and

8. To give medical aid support to the indigent in the society. ${ }^{44}$

It is therefore safe to conclude that the more lawyers in Nigeria with medico-legal background the more the patients would be educated on their medical rights and the more such rights are enforced by claims.

\subsection{Law Reporting}

Law Reporting is another vehicle for disseminating medico-legal education among judges and legal practitioners. At present most law reports in Nigeria are concentrated on Court of Appeal and Supreme Courts. The result is that many of the medical malpractice cases are not reported as they end up at the High Court. Concerted efforts should be made by the state judiciaries, legal practitioners and non-governmental organizations in medical and health rights areas to encourage law reporting of High Courts judgments. Such effort may also include establishing special law reports for medical malpractice cases only.

Closely related to the above is the absence of the report of the proceedings of the Medical and Dental Practitioners Disciplinary Tribunal. ${ }^{45}$ Even though records of such proceedings are kept by the Tribunal and the Medical and Dental Council of Nigeria, no effort has been made to publish the proceedings in the form of Law Report.

The importance of the publication of such proceedings may become more apparent when it is remembered that the tribunal has the status of a High Court and appeals lie from the Tribunal to the Court of Appeal ${ }^{46}$. Such report would certainly arm legal practitioners with the law and procedure for disciplining erring medical practitioners and by extension, promote medical right education and enforcement for lawyers and patients jointly and severally.

\section{Conclusion}

The era of arid legalism and courtroom drama of hide and seek in litigating every conceivable course of action is over. While some causes of actions naturally belong to courtroom practice, the majority of claims, especially, medical malpractice claims are more conveniently handled outside the courtroom. This paper has shown why the regular courts are not the best fora for medical malpractice claims. It recommends some administrative adjustment which could make the ordinary courts more malpractice claims friendly while highlighting other more appealing procedures which are cost effective, timesaving and easily acceptable to the even non-literate claimants. It is hoped that all stakeholders - legal practitioners, medical practitioners, public administrators, health ministries, corporations, NGOs and the general public would key into the recommended measures that respectively call for their attentions to ensure improved legal claims for medical malpractice and the corresponding rise in the quality of healthcare delivery in Nigeria.

\section{References}

Adedimeji, A. as at 23.2:11. Retrieved from https://www.independentngonline.com/dailyindependent/article.aspx

Negotiation and Conflict Management Group (NCMG). as at 12:10:10, se also Ake, Op. Cit, P.2. Retrieved from https://www.ainablankson.com

\section{Copyrights}

Copyright for this article is retained by the author(s), with first publication rights granted to the journal.

This is an open-access article distributed under the terms and conditions of the Creative Commons Attribution license (http://creativecommons.org/licenses/by/4.0/).

\footnotetext{
44 Information Brochure, Foundation for Medical Right of Nigerians.

45 Tribunal Set/up under S.16 of the Medical and Dental Practitioners Act, Cap M.8, Laws of Federation of Nigeria, 2004 to try medical and dental practitioners for professional misconducts.

46 Section $16(6)$ of the Act.
} 